[Note]

\title{
Suppression of Sludge Formation by Two-stage Catalytic Hydrodesulfurization of Arabian Atmospheric Residue
}

\author{
Kinya SAKANISHI*, Xing Zhe ZhaO, and Isao Mochida \\ Institute of Advanced Material Study, Kyushu University, \\ Kasugakouen 6-1, Kasuga, Fukuoka 816
}

(Received June 12, 1991)

\begin{abstract}
Two-stage catalytic hydrodesulfurization of Arabian atmospheric residue was studied using commercial Co-Mo and Ni-Mo catalysts in a batch autoclave to achieve a high desulfurization level without producing "dry sludge" (precipitated insoluble droplets in the product oil matrix). Single-stage reactions using a Co-Mo catalyst $(\mathrm{KF}-742)$ at 380 and $400^{\circ} \mathrm{C}$ for $3 \mathrm{~h}$ under hydrogen pressure of $c a .100 \mathrm{~atm}$ achieved desulfurizations of 62 and 75\%, respectively, with a very little amount of sludge formed. A higher reaction temperature of $420^{\circ} \mathrm{C}$ enhanced the rate of desulfurization significantly up to $86 \%$, but much sludge droplets were formed in the product oil. The two-stage hydrotreatment using KF-742 catalyst at $380^{\circ} \mathrm{C}-2 \mathrm{~h}$ followed by $420^{\circ} \mathrm{C}-1 \mathrm{~h}$ achieved high rate of desulfurization (84\%) comparable to that of the single-stage reaction at $420^{\circ} \mathrm{C}-3 \mathrm{~h}$, and produced slightly less dry sludge in the product oil. A combination of using KFR-10 catalyst in the first stage, and KF-742 catalyst in the second stage, under the same two-stage reaction conditions, markedly decreased formation of sludge droplets, although the rate of desulfurization was also reduced slightly to $80 \%$. A first stage reaction at $380^{\circ} \mathrm{C}-2 \mathrm{~h}$ with $\mathrm{KFR}-10$ catalyst followed by a second stage reaction at $410^{\circ} \mathrm{C}-2 \mathrm{~h}$ with $\mathrm{KF}-742$ catalyst improved the desulfurization level to $85 \%$ without increasing dry sludge. The mechanism of sludge formation and its suppression are discussed relative to severities of reaction conditions involved in the hydrotreatment which may also enhance the desulfurization.
\end{abstract}

\section{Introduction}

Demand for cleaner distillate from the bottom of the barrel leads to extensive hydrodesulfurization and/or hydrocracking of petroleum residues under more severe conditions ${ }^{1}$. The severe conditions cause problems of coke deposition on the catalyst and sludge formation in the product oil ${ }^{2)}$. Coke and sludge are sources of problems: these shorten the life of the catalyst, plug transfer lines and deteriorate the quality of the products ${ }^{3}$. The formation of these may be intimately related to each other.

Dry sludge is believed to be inevitably produced in both hydrodesulfurization and hydrocracking when the conversion to distillate is high. Reaction temperature must be raised to maximize level of desulfurization at the final stage in longterm operation of hydrodesulfurization, when the catalyst has become highly deactivated ${ }^{1)}$. Procedures to overcome the dilemma of sludge formation at high conversion have not yet been fully clarified ${ }^{4}$.

According to previous reports ${ }^{5)} 7$ ), dry sludge

* To whom correspondence should be addressed. produced in a hydrocracked oil from a vacuum residue is soluble in aromatic solvents such as 1methylnaphthalene, and miscible with the matrix of hydrocracked product at elevated temperatures. Hence, successive extensive hydrogenation should be effective to convert it to a miscible product at room temperature. This reasoning suggests procedures of hydrocracking that would prevent sludge formation. Accordingly, a two-stage catalytic hydrocracking was proposed to achieve higher than $50 \%$ conversion to $540^{\circ} \mathrm{C}$-distillate with a minimum formation of dry sludge. The basic idea stands on the following mechanism: deep hydrogenation of the aromatic fraction in the residue by the first lower temperature stage may enhance cracking and solubility of its heaviest portion. The enhanced cracking and solubility of the heavy fraction may suppress retrogressive reactions in the second higher temperature stage, where major hydrocracking takes place, leaving little or no dry sludge in the product.

In the present study, catalytic two-stage hydrodesulfurization of Arabian atmospheric residue was examined, using commercial Co-Mo and Ni-Mo catalysts to achieve a high level of desulfurization without producing dry sludge. 
In other words, the highest allowable non-sludgeproducing temperature of the second-stage desulfurization was sought.

\section{Experimental}

An atmospheric residue of Arabian-light crude (ALAR, $10 \mathrm{~g}$, see Table 1) was hydrotreated by single- and two-stage reactions under $100 \mathrm{~atm}$ of hydrogen. Reaction temperature was varied, and either $\mathrm{Co}-\mathrm{Mo}$ or $\mathrm{Ni}-\mathrm{Mo}$ catalyst $(\mathrm{lg}$ ) was employed. The reactions were carried out in a batch autoclave of $100 \mathrm{ml}$ capacity. The catalysts (see Table 2) were presulfided in $5 \% \mathrm{H}_{2} \mathrm{~S} / \mathrm{H}_{2}$ flow at $360^{\circ} \mathrm{C}$ for $6 \mathrm{~h}$, before the reaction.

The standard conditions were $380^{\circ} \mathrm{C}-3 \mathrm{~h}, 400^{\circ} \mathrm{C}$ $3 \mathrm{~h}$ and $420^{\circ} \mathrm{C}-3 \mathrm{~h}$ for the single-stage reaction, and $380^{\circ} \mathrm{C}-2 \mathrm{~h}$ (first stage) and $420^{\circ} \mathrm{C}-1 \mathrm{~h}$ or $410^{\circ} \mathrm{C}-2 \mathrm{~h}$ (second stage) for the two-stage reaction. After replacing the atmosphere in the autoclave with hydrogen, the reactor was pressurized with hydrogen and heated up to the reaction temperature at heating rate of $c a .8^{\circ} \mathrm{C} / \mathrm{min}$. After the first stage reaction, the reactor was cooled to room temperature, and pressurized with fresh hydrogen, followed by the second stage reaction at heating rate same as the first stage reaction.

After recovery of the reaction mixture from the autoclave, the catalyst was filtered and washed with THF. The product oil, which was recovered by evaporating out the THF, was analyzed by a sulfur-microanalysis system (Yoshida Science Co.) to estimate the level of desulfurization. The recovered product oil was also observed under an optical microscope to examine the presence of dry sludge of insoluble precipitates. The amount of sludge was always $<0.1 \mathrm{wt} \%$, under the present conditions.

\section{Results}

\section{1 Properties of Original ALAR}

The original ALAR contains $4.1 \mathrm{wt} \%$ hexane-

Table 1 Elemental Analyses of ALAR and Its Fractions a)

\begin{tabular}{lcrrrrrr}
\hline \multirow{2}{*}{ Sample } & $\begin{array}{c}\text { Contents } \\
{[\mathrm{wt} \%]}\end{array}$ & \multicolumn{6}{c}{ wt\% } \\
\cline { 3 - 8 } & & \multicolumn{1}{c}{$\mathrm{H}$} & $\mathrm{N}$ & $\mathrm{S}$ & $\mathrm{O}^{\text {b) }}$ & Ash \\
\hline ALAR-OR & - & 85.1 & 11.3 & 0.23 & 3.24 & 0.15 & - \\
HS & 95.9 & 85.1 & 11.6 & 0.20 & 3.01 & 0.12 & - \\
HI & 4.1 & 83.9 & 7.0 & 0.95 & 6.62 & 1.12 & 0.39 \\
\hline
\end{tabular}

a) HS: hexane solubles, HI: hexane insolubles.

b) Difference.

Table 2 Properties of Catalysts

\begin{tabular}{lcccccc}
\hline Name & Support & $\begin{array}{c}\text { S.A. } \\
{\left[\mathrm{m}^{2} / \mathrm{g}\right]}\end{array}$ & \multicolumn{4}{c}{$\begin{array}{c}\text { Metal load } \\
{[\mathrm{wt} \%]}\end{array}$} \\
\hline KF-742 & alumina & 268 & $\mathrm{CoO}$ & 4.4 & $\mathrm{MoO}_{3}$ & 15 \\
KFR-10 & alumina & 147 & $\mathrm{NiO}$ & 1.0 & $\mathrm{MoO}_{3}$ & 5.0 \\
\hline
\end{tabular}

insolubles (HI), where major heteroatoms and metals are concentrated. No insoluble precipitate was observed in the hexane-soluble (HS) matrix under an optical microscope (Fig. 1(a)), indicating that the HI fraction was dissolved or homogeneously dispersed in the HS matrix of the original

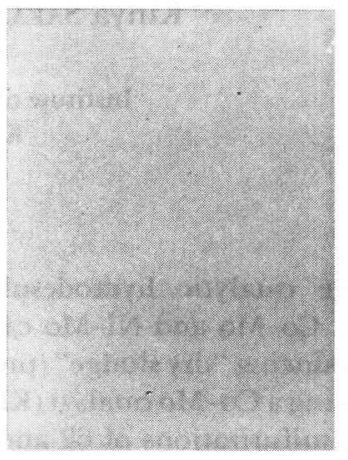

(a) Original ALAR

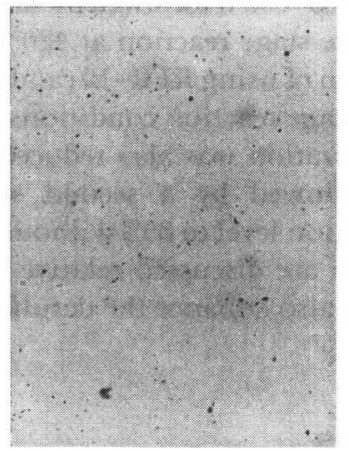

(b) Hydrotreated ALAR at $380^{\circ} \mathrm{C}-3 \mathrm{~h}$ ( $\mathrm{KF}-742$ catalyst)

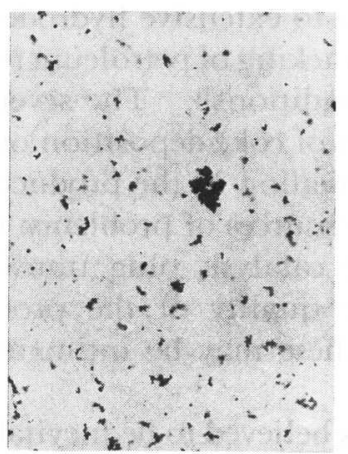

(c) Hydrotreated ALAR at $420^{\circ} \mathrm{C}-3 \mathrm{~h}(\mathrm{KF}-742$ catalyst)

Fig. 1 Microphotographs of ALAR before and after the Single-stage Hydrodesulfurization

Table 3 Single-stage Hydrotreatment of AL.AR

\begin{tabular}{cccc}
\hline $\begin{array}{c}\text { Reaction } \\
\text { conditions }^{\text {a) }}\end{array}$ & $\begin{array}{c}\text { S content } \\
{[\mathrm{wt} \%]}\end{array}$ & $\begin{array}{c}\text { HDS }^{\text {b) }} \\
{[\%]}\end{array}$ & Amount of sludge \\
\hline $380^{\circ} \mathrm{C}-3 \mathrm{~h}$ & 1.24 & 62 & Trace \\
$400^{\circ} \mathrm{C}-3 \mathrm{~h}$ & 0.81 & 75 & Trace \\
$420^{\circ} \mathrm{C}-3 \mathrm{~h}$ & 0.44 & 86 & Some \\
\hline
\end{tabular}

a) Catalyst: $\mathrm{KF}-742, \mathrm{H}_{2}$ reaction press.: $100 \mathrm{~atm}$.

b) Hydrodesulfurization (sulfur removal). 


\section{ALAR.}

\section{2 Single-stage Hydrodesulfurization}

Table 3 summarizes the results of single-stage hydrodesulfurization using the $\mathrm{Co}-\mathrm{Mo}$ catalyst (KF-742). The reactions at 380 and $400^{\circ} \mathrm{C}$ provided desulfurizations of 62 and $75 \%$, respectively, with very little sludge formation (Fig. $\mathbf{l}(\mathbf{b}))$.

A higher reaction temperature of $420^{\circ} \mathrm{C}$, for $3 \mathrm{~h}$, increased the rate of desulfurization significantly up to $86 \%$. Much sludge droplets were found in the product oil (Fig. I(c)), although about half of the asphaltenes (HI) was certainly converted into HS under the conditions.

\section{3 Two-stage Hydrodesulfurization}

Results of two-stage hydrodesulfurization are summarized in Table 4. The two-stage hydrode- sulfurization, using $\mathrm{KF}-742$ catalyst in both stages at $380^{\circ} \mathrm{C}-2 \mathrm{~h}$ and $420^{\circ} \mathrm{C}-1 \mathrm{~h}$, produced many sludge droplets in the product oil (Fig. 2(a)). However, the amount was certainly less than that found after the single-stage desulfurization at $420^{\circ} \mathrm{C}-3 \mathrm{~h}$, in spite of the same level of desulfurization (as high as $84 \%)$.

A combination of $\mathrm{KFR}-10$ catalyst in the first stage with KF-742 catalyst in the second stage, under the same reaction conditions, significantly decreased the number of sludge droplets (Fig. $2\left(b_{2}\right)$ ), although the desulfurization level was also reduced slightly, to $80 \%$. The second stage reaction at $410^{\circ} \mathrm{C}-2 \mathrm{~h}$ (a lower reaction temperature and a longer reaction time), with $\mathrm{KF}-742$, after the same first stage reaction at $380^{\circ} \mathrm{C}-2 \mathrm{~h}$ with $\mathrm{KFR}-10$, enhanced the desulfurization up to $85 \%$ without

Table 4 Two-stage Hydrotreatment of ALAR

\begin{tabular}{|c|c|c|c|c|}
\hline \multicolumn{2}{|c|}{ Conditions (catalyst) } & \multirow{2}{*}{$\begin{array}{c}\text { S content } \\
{[w t \%]}\end{array}$} & \multirow{2}{*}{$\begin{array}{c}\text { HDS } \\
{[\%]}\end{array}$} & \multirow{2}{*}{ Amount of sludge } \\
\hline lst & 2nd & & & \\
\hline $380^{\circ} \mathrm{C}-2 \mathrm{~h}(\mathrm{KF}-742)$ & $420^{\circ} \mathrm{C}-1 \mathrm{~h}(\mathrm{KF}-742)$ & 0.53 & 84 & Some \\
\hline $380^{\circ} \mathrm{C}-2 \mathrm{~h}(\mathrm{KFR}-10)$ & $420^{\circ} \mathrm{C}-1 \mathrm{~h}(\mathrm{KF}-742)$ & 0.64 & 80 & Trace \\
\hline $380^{\circ} \mathrm{C}-2 \mathrm{~h}(\mathrm{KFR}-10)$ & $410^{\circ} \mathrm{C}-2 \mathrm{~h}(\mathrm{KF}-742)$ & 0.49 & 85 & Trace \\
\hline
\end{tabular}

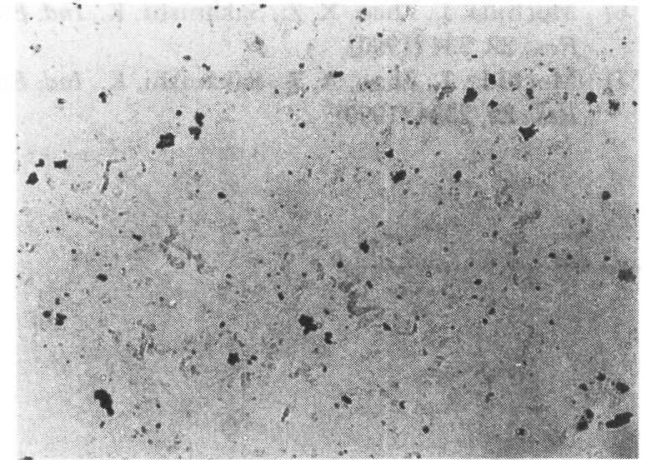

(a) Ist stage: $380^{\circ} \mathrm{C}-2 \mathrm{~h}(\mathrm{KF}-742)$ and 2 nd stage: $420^{\circ} \mathrm{C}$ $1 \mathrm{~h}(\mathrm{KF}-742)$

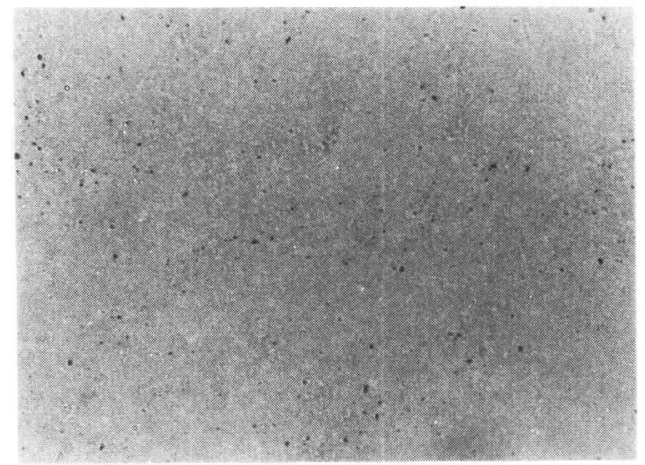

$\left(\mathrm{b}_{2}\right)$ lst stage: $380^{\circ} \mathrm{C}-2 \mathrm{~h} \quad(\mathrm{KFR}-10)$ and 2nd stage: $420^{\circ} \mathrm{C}-1 \mathrm{~h}(\mathrm{KF}-742)$

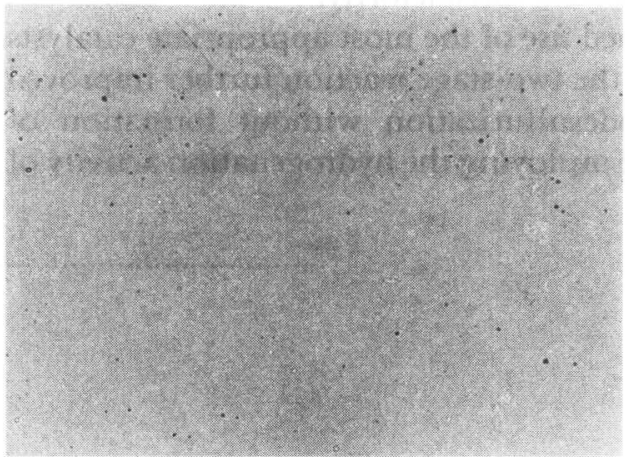

(b1) lst stage: $380^{\circ} \mathrm{C}-2 \mathrm{~h}(\mathrm{KFR}-10)$

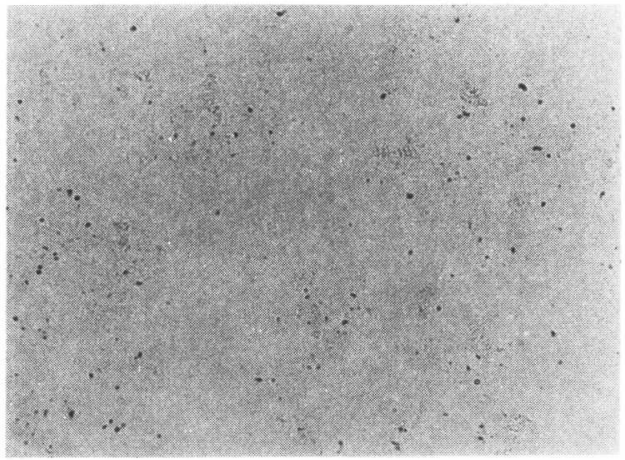

(c) lst stage: $380^{\circ} \mathrm{C}-2 \mathrm{~h}(\mathrm{KFR}-10)$ and 2 nd stage: $410^{\circ} \mathrm{C}$ $2 \mathrm{~h}(\mathrm{KF}-742)$

Fig. 2 Microphotographs of ALAR after the Two-stage Hydrodesulfurization 
any definite increase of sludge droplets (Fig. 2(c)). The $\mathrm{H} / \mathrm{C}$ atomic ratio of the product increased to 1.65 from 1.59 of the original ALAR by the first stage with KFR-10 catalyst, while the ratio increased to 1.63 with $\mathrm{KF}-742$ catalyst.

\section{Discussions}

The present study revealed that catalytic twostage hydrodesulfurization of Arabian atmospheric residue using commercial Co-Mo and Ni-Mo catalysts is very effective in achieving a higher desulfurization level of $85 \%$ with reduced dry sludge formation, relative to single-stage hydrodesulfurization. With the single-stage reaction it is possible to achieve deep desulfurization at higher temperatures $\left(>410^{\circ} \mathrm{C}\right)$ using Co-Mo catalyst. Sludge formation, however, is inevitable. Only a small number of sludge droplets are formed in the single-stage reaction at lower temperatures $\left(<400^{\circ} \mathrm{C}\right)$, but the desulfurization level of $70 \%$ is barely reached. In contrast, the two-stage hydrodesulfurization procedure, consisting of extensive hydrogenation at a lower temperature of $380^{\circ} \mathrm{C}$ in the first stage, and deep desulfurization at a higher temperature of $420^{\circ} \mathrm{C}$ in the second stage, solves the dilemma of the singlestage treatment, satisfactorily.

Combined use of the most appropriate catalysts at each of the two-stage reaction further improved the hydrodesulfurization without formation of sludge. Employing the hydrogenation activity of
$\mathrm{Ni}$-Mo catalyst for the asphaltene fraction in the first stage and hydrodesulfurization activity of Co-Mo catalyst, with minimum hydrogen consumption in the second stage, may be the most appropriate two-stage reaction. More effective catalysts for improved performance, emphasized in each step, can be designed easily, because their respective mono-function is to be separately enhanced.

It is of value to point out that the reaction condition, especially temperature, which may be the most influential factor on both desulfurization and sludge formation, can be separately optimized, at the respective stages, for the best total performance.

\section{References}

1) Saito, K., Shimizu, S., PETROTECH, 8, (1), 54 (1985).

2) Symoniak, M. F., Frost, A. C., Oil \& Gas J., March 15, 76 (1971).

3) Mckenna, W. L., Owen, G. H., Mettick, G. R., Oil \& Gas J., 62, (20), 106 (1964).

4) Haensel, V., Addison, G. E., Advances in Catalytic Reforming, 7th World Petroleum Congress, 4, 113 (1967).

5) Mochida, I., Zhao, X. Z., Sakanishi, K., Yamamoto, S., Takashima, H., Uemura, S., Ind. Eng. Chem. Res., 28, 418 (1989).

6) Mochida, I., Zhao, X. Z., Sakanishi, K., Ind. Eng. Chem. Res., 29, 334 (1990)

7) Mochida, I., Zhao, X. Z., Sakanishi, K., Ind. Eng. Chem. Res., 29, 2324 (1990). 
要 旨

\section{アラビアン常圧残さの接触二段水秦化脱硫によるスラッジ生成の抑制}

坂西欣也, 趙 與哲, 持田 勲

九州大学機能物質科学研究所, 816 福岡県春日市春日公園 6-1

振とう式オートクレーブ（内容積: $100 \mathrm{cc}$ ) を用いて, 反応 温度: $380 \sim 420^{\circ} \mathrm{C}$, 反応水素圧: $100 \mathrm{~atm}$ の条件下で, 市販の Co-Mo（KF-742）あるいは Ni-Mo（KFR-10）触媒によるア ラビアン常圧残さの単段および二段水素化脱硫処理を行い, 精 製油中にスラッジを生成せずに高い脱硫率を達成できる反応条 件を探索した。KF-742 を用いる $380^{\circ} \mathrm{C}$ および $400^{\circ} \mathrm{C}-3 \mathrm{~h}$ の単 段反応では，極く少量のスラッジしか生成しなかったものの, 脱硫率はそれぞれ $62 ， 75 \%$ にとどまった。 $420^{\circ} \mathrm{C}-3 \mathrm{~h}$ の高温 単段反応では, $86 \%$ の高い脱硫率が達成できたが, 精製油中 に多くのスラッジ粒子が生成した。一方, 両段で KF-742 触 媒を用いる $380^{\circ} \mathrm{C}-2 \mathrm{~h}$ および引き続く $420^{\circ} \mathrm{C}-1 \mathrm{~h}$ の二段反応
では，高温単段反応に匹敵する脱硫率 $(84 \%)$ が得られ，かつ 精製油中の生成スラッジ粒子は高温単段反応より少量であっ た。同一反応条件下の二段反応において，KFR-10（第 1 段） および KF-742（第 2 段）触媒を組み合わせて用いると，精製 油中のスラッジ粒子数は顕著に滅少したものの, 脱硫率 (80\%) も若干隇少した。第 1 段: $380^{\circ} \mathrm{C}-2 \mathrm{~h}$ (KFR-10 触媒) および引き続く $410^{\circ} \mathrm{C}-2 \mathrm{~h}(\mathrm{KF}-742$ 触媒）の二段水素化脱硫 処理を行うと, 生成スラッジ粒子を増大させることなく, 脱硫 率を $85 \%$ まで上昇できた。スラッジ生成とその抑制機構につ いて，脱硫率を最大限にする反応条件と関連付けて考察した。

\section{Keywords}

Hydrodesulfurization, Atmospheric residue, Sludge formation, Cobalt-molybdenum catalyst, Nickel-molybdenum catalyst 